N. M. Kononenko, V. V. Chikitkina, M. V. Sorokyna, M. O. Ostapets

National University of Pharmacy

\title{
The effect of the Ginger dry extract on the indicators of the carbohydrate metabolism under conditions of the experimental metabolic syndrome in Syrian golden hamsters
}

Aim. To study the effect of the ginger dry extract on the indicators of the carbohydrate metabolism in the experimental metabolic syndrome.

Materials and methods. The effect of the ginger dry extract on the carbohydrate metabolism was determined by the level of basal glycemia, basal insulinemia, HOMA-IR index, HbA1c level, the glycogen content in the liver and the body weight against the background of the metabolic syndrome induced by a high-calorie diet in Syrian golden hamsters.

Results and discussion. Consumption of high-calorie food for 6 weeks led to development of the metabolic syndrome, it was confirmed by an increase in the body weight, hyperglycemia, compensatory insulinemia, insulin resistance, increased glycogenolysis in the liver and glycosylation of proteins. The use of the ginger dry extract in the dose of $80 \mathrm{mg} / \mathrm{kg}$ over the period of 14 days reliably reduced blood glucose by $43.3 \%$ and normalized insulinemia by $32.8 \%$ affecting a decrease in the HOMA-IR index. The introduction of the ginger extract in the dose of $80 \mathrm{mg} / \mathrm{kg} \mathrm{was}$ also accompanied by suppression of protein glycosylation by $29.6 \%$ and restoration of glycogen-forming function of the liver. By its ability to restore the carbohydrate metabolism the ginger dry extract in the dose of $80 \mathrm{mg} / \mathrm{kg} \mathrm{did} \mathrm{not}$ differ from metformin and exceeded the effectiveness of the herbal drug "Arphasetin". It is probably due to the powerful complex pharmacological action of phenolic compounds of ginger - gingerols and other components.

Conclusions. On the experimental model of the metabolic syndrome the use of the ginger dry extract normalized blood glucose, insulinemia, decreased insulin resistance and restored the glycogen content in the liver at the level of metformin. By the intensity of the pharmacological action the ginger extract exceeded the reference herbal drug "Arphasetin". This fact is the basis for its further pharmacological study as a promising agent for the treatment of the metabolic syndrome and type 2 diabetes.

Key words: Ginger dry extract; metabolic syndrome; high-calorie diet; carbohydrate metabolism

Н. М. Кононенко, В. В. Чікіткіна, М. В. Сорокіна, М. О. Остапець

Вплив сухого екстракту імбиру на показники вуглеводного обміну за умови експериментального метаболічного синдрому у сирійських золотавих хом'ячків

Мета - вивчення впливу сухого екстракту імбиру на показники вуглеводного обміну за умови експериментального метаболічного синдрому.

Матеріали та методи. Визначення впливу сухого екстракту імбиру на вуглеводний обмін проводили за рівнем базальної глікемії, базальної інсулінемії, індексом HOMA-IR, рівнем HbA1c, вмістом глікогену у печінці та масою тіла на тлі метаболічного синдрому, індукованого висококалорійною дієтою у сирійських золотавих хом'ячків.

Результати та їх обговорення. Споживання висококалорійної їжі впродовж 6 тижнів призводило до розвитку метаболічного синдрому, що підтверджувалось збільшенням маси тіла, гіперглікемією, компенсаторною інсулінемією, інсулінорезистентністю, посиленням процесів глікогенолізу у печінці та глікозилювання білків. Застосування сухого екстракту імбиру дозою 80 мг/кг впродовж 14 днів достовірно на 43,3 \% знижувало рівень глюкози в крові та на 32,8 \% нормалізувало інсулінемію, що відображалося зменшенням індексу HOMA-IR. Уведення екстракту імбиру дозою 80 мг/кг також супроводжувалось пригніченням процесу глікозилювання білків на 29,6 \% та відновленням глікогеноутворювальної функції печінки. За здатністю відновлювати показники вуглеводного обміну сухий екстракт імбиру дозою 80 мг/кг не відрізнявся від метформіну та перевищував ефективність збору «Арфазетин», що, можливо, обумовлено потужною комплексною фармакологічною дією фенольних сполук імбиру - гінгеролів та інших складових компонентів.

Висновки. На експериментальній моделі метаболічного синдрому застосування сухого екстракту імбиру нормалізувало глікемію, інсулінемію, зменшувало інсулінорезистентість та відновлювало вміст глікогену у печінці на рівні метформіну. За виразністю фрармакологічної дії екстракт імбиру переважав препарат порівняння збір «Арфазетин», що є обґрунтуванням подальшого фрармакологічного вивчення екстракту імбиру як перспективного засобу для лікування метаболічного синдрому та ЦД 2 типу.

Ключові слова: сухий екстракт імбиру; метаболічний синдром; висококалорійна дієта; вуәлеводний обмін 
Н.Н.Кононенко, В. В. Чикиткина, М.В.Сорокина, М. А. Остапец

\section{Влияние сухого экстракта имбиря на показатели углеводного обмена при экспериментальном метаболическом синдроме у сирийских золотистых хомячков}

Цель - изучение влияния сухого экстракта имбиря на показатели углеводного обмена при экспериментальном метаболическом синдроме.

Материалы и методы. Определение влияния сухого экстракта имбиря на углеводный обмен проводили по уровню базальной гликемии, базальной инсулинемии, индексу HOMA-IR, уровню HbA1c, содержанию гликогена в печени и по массе тела на фроне метаболического синдрома, индуцированного высококалорийной диетой у сирийских золотистых хомячков.

Результаты и их обсуждение. Потребление высококалорийной пищи в течение 6 недель приводило к развитию метаболического синдрома, что подтверждалось увеличением массы тела, гипергликемией, компенсаторной инсулинемией, инсулинорезистентностью, усилением процессов гликогенолиза в печени и гликозилирования белков. Применение сухого экстракта имбиря в дозе 80 мг/кг в течение 14 дней достоверно на 43,3 \% снижало уровень глюкозы в крови и на 32,8 \% нормализовало инсулинемию, что отражалось уменьшением индекса HOMA-IR. Введение экстракта имбиря в дозе 80 мг/кг также сопровождалось угнетением процесса гликозилирования белков на 29,6 \% и восстановлением гликогенообразовательной функции печени. По способности восстанавливать показатели углеводного обмена сухой экстракт имбиря в дозе 80 мг/кг не отличался от метформина и превышал эффрективность сбора «Арфазетин», что, возможно, обусловлено мощным комплексным фармакологическим действием фенольных соединений имбиря - гингеролов и других составляющих компонентов.

Выводы. На экспериментальной модели метаболического синдрома применение сухого экстракта имбиря нормализовало уровень глюкозы в крови, инсулинемии, уменьшало инсулинорезистентность и восстанавливало содержание гликогена в печени на уровне метформина. По выразительности фрармакологического действия экстракт имбиря превышал препарат сравнения сбор «Арфазетин», что является обоснованием для его дальнейшего фрармакологического изучения в качестве перспективного средства для лечения метаболического синдрома и СД 2 типа.

Ключевые слова: сухой экстракт имбиря; метаболический синдром; высококалорийная диета; углеводный обмен

According to the modern concepts the metabolic synd rome (MS) is a complex of metabolic, hormonal and clinical disorders that can be as factors of high risk for development of cardiovascular diseases. The main manifestations of MS are the abdominal type of obesity, insulin resistance and compensatory hyperinsulinemia, dyslipidemia, arterial hypertension, glucose tolerance/ type 2 diabetes mellitus (DM), early atherosclerosis / ischemic heart disease, hemostasis disorder, hyperuricemia and gout, microalbuminuria, hyperandrogenemia [1].

Today MS attracts the attention of many experts since it precedes the emergence of type 2 diabetes mellitus (DM) and atherosclerosis - diseases that presently are major causes of mortality [2]. Increased interest is due to the fact that MS is a reversible condition - with the appropriate timely treatment the disappearance or a significant reduction of its main manifestations can be achieved.

The basic aim of the treatment of patients with MS is correction of the main components of of MS, such as insulin resistance and hyperinsulinemia, arterial hypertension, obesity and lipid metabolism disorders. Along with changes in the lifestyle and drug correction an important role in complex therapy of MS and type $2 \mathrm{DM}$ is played by herbal products that due to a wide range of the pharmacological action can regulate the carbohydrate and the metabolism, blood pressure, blood rheology, normalize the body weight. The results of numerous experimental and clinical studies indicate the hypoglycemic, hypolipidemic, antioxidant properties that plants exhibit, including ginger, which is a famous spice, and the source of useful and medicinal substances [3-5]. Biologically active substances developed on the basis of ginger root are used for the prevention and treatment of different diseases as anti-inflammatory, antitumor, antioxidant, antidiabetic drugs. It has been found that ginger decreases glucose levels in the blood, enhances glycogen genesis, improves the synthesis of insulin and reparative properties of the pancreas, and normalizes the lipid metabolism $[6,7]$.

The aim of the work was to study the effect of the ginger dry extract on the indicators of the carbohydrate metabolism in the experimental metabolic syndrome induced in Syrian golden hamsters.

\section{Materials and methods}

A dry extract of common ginger (Zingiber officinale) produced by "Medagroprom", Dnipro, was obtained from the ginger rhizomes by extraction with $50 \%$ alcohol and spray drying. The ginger dry extract (IMB) contains phenolic compounds - gingeroles (not less than $5 \%$ ) that provide its pharmacological activity, and a dry residue (at least 95\%).

In the experiment Syrian golden male hamsters ( 20 weeks old at the beginning of the experiment) were used; they were kept under standard conditions in the vivarium of the Central Research Laboratory of the National University of Pharmacy at a temperature of $22 \pm 1{ }^{\circ} \mathrm{C}$, humidity of $50-60 \%$, in a room with changing the day or night light regimes. 
The metabolic syndrome was modeled by keeping the hamsters on a high-calorie (hypercaloric) diet rich in energy (containing $29 \%$ of fats - mainly saturated lipids) and fructose $(1 \mathrm{~g}$ a day per $100 \mathrm{~g}$ of the body weight) as an aqueous solution for 6 weeks [8].

Hamsters were divided into the following experimental groups: group 1 - animals of the intact control (IC); group 2 - animals of the control pathology (CP), they were kept on a high-calorie diet for 6 weeks; groups 3 and 4 - animals that starting from the 4 th week of the experiment were injected intragastrically with an aqueous solution of the ginger extract in the doses of 50 and $80 \mathrm{mg} / \mathrm{kg}$ for 14 days (IMB50, IMB80) against the background of a high-calorie diet; groups 5 and 6 - animals that starting from the 4-th week of the experiment against the background of a high-calorie diet were injected intragastrically the reference drugs: an infusion of the antidiabetic herbal drug "Arphasetin" (produced by "Liktravy", Ukraine) in the dose of $16 \mathrm{ml} / \mathrm{kg}$ and a hypoglycemic drug metformin from the group of biguanides in the dose of $60 \mathrm{mg} / \mathrm{kg}$ for 14 days.

On the 1st day before the start and after 6 weeks of the experiment the body weight of animals was measured.

The state of the carbohydrate metabolism against the background of the model pathology was assessed by the level of basal glycemia and basal insulinemia [9].

The glucose concentration in the blood serum of animals was determined on an empty stomach by the glucose oxidase method using a "One touch ultra-easy" glucose meter (manufactured by LifeScan, Johnson \& Johnson, USA).

The concentration of insulin in the blood serum was determined by the immunoassay method using a standard kit of "DRG" reagents (manufactured in Germany).

The index of insulin resistance (HOMA-IR index) was calculated based on the values of glucose and insulin in the blood of animals on an empty stomach using the HOMA algorithm (Homeostasis Model Assessment) [10].

The level of glycosylated hemoglobin (HbAlc), an important criterion for the compensation of diabetes mellitus and MS, was determined by the immuno-turbidimetric method using an Erba Lachema kit (Czech Republic).

At the end of the experiment the animals were decapitated under etheric anesthesia, and the glycogen content was determined in the liver homogenates using standard biochemical kits of domestic production [11].

The statistical processing of the results was performed on a personal computer using Excel packages and Statistica 6.0 for Windows. The Newman-Keys and ManaWhitney tests were used to determine the probable differences between the experimental groups. Differences were considered statistically significant at $\mathrm{p}<0.05$.

\section{Results and discussion}

It is known that consumption of high calorie food leads to obesity that is closely associated with the risk of developing MS and type 2 diabetes. Keeping animals on a hypercaloric high-fructose diet for 6 weeks resulted in obesity since the increase in the body weight in CP hamsters was significantly 3 times greater than the same indicator in IC group (Table).

At the same time, in CP animals the severe hyperglycemia and hyperinsulinemia with a significant increase of glucose and insulin levels by 3.0 and 1.63 times, respectively, were developed compared to IC (Table). It is known that the simultaneous increase of glucose and insulin levels is considered as a manifestation of insulin resistance. To confirm it the HOMA-IR index was calculated, it increased significantly by 2.33 times compared to the IC group (Table). It indicated formation of severe disorders of the carbohydrate metabolism and development of insulin resistance as one of the main pathogenetic links of MS.

Table

The effect of the ginger dry extract on the indicators of the carbohydrate metabolism in the experimental metabolic syndrome

\begin{tabular}{|c|c|c|c|c|c|c|}
\hline Indicator & $\mathrm{IC}$ & $C P$ & IMB50 & IMB80 & "Arphasetin" & Metformin \\
\hline Glucose, mmol/l & $\begin{array}{c}5.18 \pm \\
0.48\end{array}$ & $\begin{array}{c}13.57 \pm \\
0.55^{*}\end{array}$ & $\begin{array}{c}9.59 \pm \\
0.57^{* * * *}\end{array}$ & $\begin{array}{l}6.70 \pm \\
0.52^{* * *}\end{array}$ & $\begin{array}{c}8.88 \pm \\
0.52^{* * * *}\end{array}$ & $\begin{array}{l}6.40 \pm \\
0.21^{* *}\end{array}$ \\
\hline Insulin pmol/I & $\begin{array}{c}82.55 \pm \\
2.32\end{array}$ & $\begin{array}{c}134.18 \pm \\
2.22^{*}\end{array}$ & $\begin{array}{c}113.17 \pm \\
3.44^{*}\end{array}$ & $\begin{array}{c}90.12 \pm \\
1.25 * / * * / a\end{array}$ & $\begin{array}{l}95.93 \pm \\
1.89^{* / * *}\end{array}$ & $\begin{array}{c}89.03 \pm \\
1.25 * / * * / a\end{array}$ \\
\hline HOMA-IR & 1.55 & $3.61^{*}$ & $2.68^{*}$ & $1.93^{* *}$ & $2.21 * / * *$ & $1.81^{* *}$ \\
\hline $\mathrm{HbA} 1 \mathrm{c}, \%$ & $\begin{array}{l}5.9 \pm \\
0.22\end{array}$ & $\begin{array}{l}9.8 \pm \\
0.53^{*}\end{array}$ & $\begin{array}{c}7.3 \pm \\
0.43^{*} / * *\end{array}$ & $\begin{array}{c}6.9 \pm \\
0.28^{* *}\end{array}$ & $\begin{array}{c}7.3 \pm \\
0.52^{* * * *}\end{array}$ & $\begin{array}{c}7.2 \pm \\
0.48^{*} / * *\end{array}$ \\
\hline $\begin{array}{l}\text { Glycogen of the } \\
\text { liver, } \mathrm{mg} / 100 \mathrm{~g} \text { of } \\
\text { the tissue }\end{array}$ & $\begin{array}{c}2326.5 \pm \\
219.41\end{array}$ & $\begin{array}{c}1098.3 \pm \\
103.94^{*}\end{array}$ & $\begin{array}{l}1873.5 \pm \\
304.62^{* *}\end{array}$ & $\begin{array}{l}2146.2 \pm \\
251.18^{* *}\end{array}$ & $\begin{array}{c}1439.5 \pm \\
244.57^{* *} / a\end{array}$ & $\begin{array}{c}2165.0 \pm \\
275.34^{* *} / a\end{array}$ \\
\hline $\begin{array}{c}\text { Increase in the } \\
\text { body weight } \\
\text { within } 6 \text { weeks, g }\end{array}$ & $\begin{array}{c}30.5 \pm \\
3.3\end{array}$ & $\begin{array}{l}92.3 \pm \\
6.3^{*}\end{array}$ & $\begin{array}{l}44.5 \pm \\
4.2^{* * * *}\end{array}$ & $\begin{array}{l}34.5 \pm \\
5.3^{* *} / a\end{array}$ & $\begin{array}{l}54.3 \pm \\
7.3^{*} / * *\end{array}$ & $\begin{array}{l}33.5 \pm \\
5.2^{* * / a}\end{array}$ \\
\hline
\end{tabular}

Notes: ${ }^{*}$ - statistically significant difference in relation to the values of IC group $(p \leq 0.05)$; ${ }^{* *}$ - statistically significant difference in relation to the values of CP group ( $\leq \leq 0.05)$; $a$ - statistically significant difference in relation to the values of the group taking "Arphasetin" ( $p \leq 0.05)$. 
Disorders of glucose utilization in CP hamsters were also characterized by a decrease in the glycogen stores in the liver by 2 times. It confirms development of liver resistance to the insulin action, which results in the processes of glycogenolysis and gluconeogenesis (Table).

On the background of chronic hyperglycemia the increase of HbAlc content by $66.1 \%$ was observed compared to the IC indicators. It indicated a high level of glycosylation of proteins in this model of MS.

Therefore, changes in the indicators characterizing the state of the carbohydrate metabolism of golden hamsters kept on the high-calorie diet indicate simulation of the MS state characterized by hyperglycemia, compensatory hyperinsulinemia, insulin resistance, increased glycogenolysis in the liver and glycosylation of proteins.

According to the data presented in Table the body weight increased in all experimental hamsters, but dynamics of its increasing in animals receiving IMB in the dose of $80 \mathrm{mg} / \mathrm{kg}$ and metformin did not statistically differ from the group of IC. The ginger extract in the dose of $50 \mathrm{mg} / \mathrm{kg}$ moderately inhibited development of obesity in a similar way as the reference drug "Arphasetin".

The use of IMB for 14 days simultaneously with the hypercaloric diet was accompanied with a possible decrease in the indicators reflecting the state of the glycemic profile. It should be noted that the maximum therapeutic effect was observed with the use of IMB in the dose of $80 \mathrm{mg} / \mathrm{kg}$. Thus, the intragastric introduction of IMB in the dose of $80 \mathrm{mg} / \mathrm{kg}$ was accompanied by a significant reduction in the severity of hyperglycemia by $43.3 \%$ compared to CP animals at the metformin level, while using it in the dose of $50 \mathrm{mg} / \mathrm{kg}$ resulted in decreasing of this indicator by $29.2 \%$. The level of glucose at the end of the experiment in the groups of IMB80 and metformin, unlike IMB50 and "Arphasetin", did not significantly differ from the value of IC although it did not normalize completely. The data obtained reflect the expressed acceleration of glucose utilization under the effect of IMB80 in the conditions of the experimental MS.

There is clinical evidence that hyperinsulinemia is an independent risk factor for coronary heart disease [10]. Insulin has a direct atherogenic effect on the walls of vessels, adding a significant contribution to development and progression of atherosclerosis. Under the effect of IMB, probably due to decrease of hypoglycaemia, hyperinsulinemia decreased too, it was confirmed by decrease in the insulin level by $15.7 \%$ compared to IC in case of using IMB in the dose of $50 \mathrm{mg} / \mathrm{kg}$ and by $32.8 \%$ in case of introduction of IMB in the dose of $80 \mathrm{mg} / \mathrm{kg}$. The process of normalizing insulin in the group of IMB80 was the same as in the metformin group and significantly exceeded the effect of "Arphasetin" and IMB50.

Confirmation of the corrective effect on insulin resistance manifestations was a significant decrease in the
HOMA-IR index by 46.5 and $49.8 \%$ in hamsters receiving IMB in the dose of $80 \mathrm{mg} / \mathrm{kg}$ and metformin in animals of the CP group. The percentage of HOMA-IR decreased under the effect of IMB in the dose of $50 \mathrm{mg} / \mathrm{kg}$ and "Arphasetin" compared to $\mathrm{CP}$, and it was 25.7 and $38.8 \%$, respectively.

The determination of $\mathrm{HbAlc}$ is considered to be a criterion for normalization of the carbohydrate metabolism and the effectiveness of the metabolic control, which should be at the level of $6.5 \%$, and if the potential hypoglycaemic agent is used, it is the confirmation of its ability to reduce the risk of micro- and macrovascular complications of diabetes [11]. Under the conditions of our experiment the introduction of IMB in the dose of $50 \mathrm{mg} / \mathrm{kg}$ was accompanied with the decrease in the $\mathrm{HbA} 1$ level by $25.6 \%$ compared to "Arphasetin", while decrease of this indicator by $29.6 \%$ when using IMB 80 was consistent with the metformin effect.

Consequently, IMB did not differ from metformin and exceeded the effectiveness of the herbal drug "Arphasetin" by the effect on the level of glucose, the HOMA-IR index and HbA1c. It is probably due to the powerful complex pharmacological action of phenolic compounds of ginger - gingerols and other components having hypoglycemic, antioxidant, antidiabetic properties according to the literature data [3-5].

The ability to restore the glycogen-forming function of the liver IMB in the dose of $80 \mathrm{mg} / \mathrm{kg}$ was on the same level with metformin and reliably exceeded the effect of "Arphasetin".

Thus, the results obtained indicate the ability of IMB to normalize the carbohydrate metabolism, reduce manifestations of insulin resistance under the conditions of the experimental MS and confirm the feasibility of its further study as an antidiabetic drug.

\section{CONCLUSIONS}

1. Keeping hamsters on a hypercaloric high-fructose high-calorie diet for 6 weeks led to manifestations of the metabolic syndrome, it was confirmed by development of hyperglycemia, hyperinsulinemia, the increase of the HOMA-IR index, the level of HbAlc and the decrease of the liver glycogen content.

2. The use of the ginger extract in the dose of $80 \mathrm{mg} / \mathrm{kg}$ normalized insulin glycemia, decreased insulin resistance restored the glycogen content in the liver at the level of metformin. By the intensity of the pharmacological action the ginger extract exceeded the reference herbal drug "Arphasetin".

3. The results obtained substantiate the further pharmacological study of the ginger extract as a promising agent for the treatment of the metabolic syndrome and type 2 diabetes.

Conflict of Interests: authors have no conflict of interests to declare. 


\section{REFERENCES}

1. Метаболічний синдром : діагностика та профілактика в практиці сімейного лікаря / В. І. Ткаченко, Т. О. Багро, Н. В. Видиборець, О. К. Бондар // Ліки України. - 2016. - № 1-2 (197-198). - С. 43-46.

2. Сахарный диабет и атеросклероз : эпигенетические механизмы патогенеза (обзор литературы) / Л. К. Соколова, В. М. Пушкарев, Е. И. Ковзун та ін. // Укр. кардіол. журн. - 2017. - № 6. - С. 104-117.

3. Імбир : джерело рослинних ліків багатосторонньої та поліорганної дії (огляд літератури) / О. І. Волошин, Н. В. Бачук-Понич, Л. О. Волошина, В. Л. Васюк. - Фітотерапія. Часопис. - 2012. - № 2. - С. 19-22.

4. Protective Effects of Ginger (Zingiber officinale) Extract against Diabetes-Induced Heart Abnormality in Rats / B. Ilkhanizadeh, A. Shirpoor, M. H. Khadem Ansari et al. // Diabetes Metab. J. - 2016. - Vol. 40, Issue 1. - 46 p. doi: 10.4093/dmj.2016.40.1.46

5. Madkor, H. R. Modulatory effects of garlic, ginger, turmeric and their mixture on hyperglycaemia, dyslipidaemia and oxidative stress in streptozotocin-nicotinamide diabetic rats / H. R. Madkor, S. W. Mansour, G. Ramadan // Br. J. Nutr. - 2011. - Vol. 105, Issue 08.P. 1210-1207. doi: 10.1017/s0007114510004927

6. Sex and Age Differences in Lipoprotein Metabolism Proatherogenic Changes under the Experimental Metabolic Syndrome in Hamsters / A. Zagayko, G. Kravchenko, K. Strelchenko et al. // Lipoproteins - From Bench to Bedside. - 2015. doi: 10.5772/60759

7. Доклінічні дослідження лікарських засобів : метод. рекомендації / за ред. член-кор. АМН України О. В. Стефанова. - К. : Авіценна, 2001. $-528 \mathrm{c}$.

8. Homeostasis model assessment : insulin resistance and b-cell function from fasting plasma glucose and insulin concentrations in man / D. R. Matthews, J. P. Hosker, A. S.Rudenski et al. // Diabetol. - 1985. - Vol. 28, Issue 7. - P. 412-419. doi: 10.1007/bf00280883

9. Методы биохимических исследований. Липидный и энергетический обмен : учеб. пособ. / Под ред. М. И. Прохоровой. - Л. : Ленингр. ун-т, 1982.-272 с.

10. Фадеенко, Г. Д. Ожирение и риск сердечно-сосудистых заболеваний / Г. Д. Фадеенко, А. Е. Гриднев // Ліки України. - 2009. № 7 (133). - С. 55-64.

11. Нарушения углеводного обмена и церебральный атеросклероз у больных с ишемическими нарушениями мозгового кровообращения / К. В. Антонова, Р. Б. Медведев, А. А. Шабалина и др. // Клин. неврол. - 2016. - Т. 10, № 1. - С. $20-26$.

\section{REFERENCES}

1. Tkachenko, V. I., Bahro, T. O., Vydyborets, N. V., Bondar, O. K. (2016). Liky Ukraini, 1-2 (197-198), $43-46$.

2. Sokolova, L. K., Pushkarev, V. M., Kovzun, E. I., Pushkarev, V. V., Tronko, N. D. (2017). Ukrainskyi kardiolohichnyi zhurnal, 6, $104-117$.

3. Voloshyn, O. I., Bachuk-Ponych, N. V., Voloshyna, L. O., Vasiuk, V. O. (2012). Fitoterapiia. Chasopys, 2, $19-22$.

4. Ilkhanizadeh, B., Shirpoor, A., Khadem Ansari, M. hasan, Nemati, S., Rasmi, Y. (2016). Protective Effects of Ginger (Zingiber officinale) Extract against Diabetes-Induced Heart Abnormality in Rats. Diabetes \& Metabolism Journal, 40 (1), 46. doi: 10.4093/dmj.2016.40.1.46

5. Madkor, H. R., Mansour, S. W., Ramadan, G. (2010). Modulatory effects of garlic, ginger, turmeric and their mixture on hyperglycaemia, dyslipidaemia and oxidative stress in streptozotocin-nicotinamide diabetic rats. British Journal of Nutrition, 105 (08), $1210-1217$. doi: $10.1017 / \mathrm{s} 0007114510004927$

6. Zagayko, A., Kravchenko, G., Strelchenko, K., Shkapo, A., Briukhanova, T. (2015). Sex and Age Differences in Lipoprotein Metabolism Proatherogenic Changes under the Experimental Metabolic Syndrome in Hamsters. Lipoproteins - From Bench to Bedside. doi: $10.5772 / 60759$

7. Stefanov, O. V. (2001). Doklinichni doslidzhennia likarskykh zasobiv. Kyiv: Avitsena, 528.

8. Matthews, D. R., Hosker, J. P., Rudenski, A. S., Naylor, B. A., Treacher, D. F., Turner, R. C. (1985). Homeostasis model assessment: insulin resistance and ?-cell function from fasting plasma glucose and insulin concentrations in man. Diabetologia, 28 (7), $412-419$. doi: $10.1007 / \mathrm{bf00280883}$

9. Prokhorova, M. I. (1982). Metody biokhimicheskikh issledovanii. Lipidnyi i energeticheskyi obmen. L.: Leningradskii un-t, 272.

10. Fadeenko, G. D., Gridnev, A. E. (2009). Liky Ukrainy, 133 (7), 55-64.

11. Antonova, K. V., Medvedev, R. B., Shabalina, A. A., Lagoda, O. V., Tanashian, M. M. (2016). Klinicheskaia nevrologiia, 10 (1), $20-26$.

\section{Information about authors:}

Kononenko N. M., Doctor of Medicine (Dr.habil), professor, head of the Department of Pathological Physiology, National University of Pharmacy. E-mail: kononenkonn76@gmail.com

Chikitkina V. V., Candidate of Biology (PhD), associate professor of the Department of Pathological Physiology, National University of Pharmacy. E-mail: valentina.chikitkina@gmail.com

Sorokina M. V., postgraduate student of the Department of Pathological Physiology, National University of Pharmacy.

Ostapets M. O., Candidate of Medicine (PhD), teaching assistant of the Department of Pathological Physiology, National University of Pharmacy.

E-mail: marina.ostapets.22@gmail.com

Відомості про авторів:

Кононенко Н. М., д-р мед. наук, професор, завідувач кафедри патологічної фізіології, Національний фармацевтичний університет. E-mail: kononenkonn76@gmail.сот Чікіткіна В. В., канд. біол. наук, доцент кафедри патологічної фізіологіï, Національний фармацевтичний університет. E-mail: valentina.chikitkina@gmail.com Сорокіна М. В., аспірант кафедри патологічної фізіології, Національний фармацевтичний університет

Остапець М. О., канд. мед. наук, асистент кафедри патологічної фізіології, Національний фармацевтичний університет. E-mail: таrina.ostapets.22@gmail.com Сведения об авторах:

Кононенко Н. Н., д-р мед. наук, профессор, заведующая кафедрой патологической физиологии, Национальный фармацевтический университет.

E-mail: kononenkonn76@gmail.com

Чикиткина В. В., канд. биол. наук, доцент кафедры патологической физиологии, Национальный фармацевтический университет.

E-mail: valentina.chikitkina@gmail.com

Сорокина М. В., аспирант кафедры патологической физиологии, Национальный фармацевтический университет

Остапец М. А., канд. мед. наук, ассистент кафедры патологической физиологии, Национальный фармацевтический университет.

E-mail: marina.ostapets.22@gmail.com 